\title{
O pochodzeniu metropolity Józefa Sołtana
}

\author{
Antoni Mironowicz (iD) orcid/0000-0001-7856-2191 \\ Pracownia Historii Europy Środkowo-Wschodniej \\ Uniwersytet w Białymstoku \\ e-mail: amir@uwb.edu.pl
}

\section{Abstract \\ On the Origins of Metropolitan Józef Sołtan}

Metropolitan Józef Soltan was one of the most prominent hierarchs of the Orthodox Church in the Polish-Lithuanian Commonwealth in the sixteenth century. Most researchers believe that Józef Sołtan, Smolensk Orthodox Bishop (1503-1507) and later the Metropolitan of Kiev (1507-1521), was the son of Soltan Alexandrowicz and Wasylissa Chreptowiczówna, and the brother of Alexander Soltan. The findings presented in the article show that the view of the origin of the family of metropolitan Józef Sołtan from the Lohojska line is fully credible in confrontation with the names of the persons mentioned in the Supraśl book of the deceased. An analysis of the Supraśl book of the dead shows that it contains the names of people from the family of Archbishop Józef Sołtan, and that Eliasz Sołtan, a farmer from the Łohojsk region, is the same person as Metropolitan Józef Sołtan.

Keywords: Józef Sołtan, Kiev metropolitan, the Sołtan family

Słowa kluczowe: Józef Sołtan, metropolita kijowski, ród Sołtanów

Metropolita Józef Sołtan był jednym z najwybitniejszych hierarchów Cerkwi prawosławnej w Rzeczypospolitej w XVI stuleciu. Objęcie godności metropolity w 1507 roku zapoczątkowało największy rozwój struktur cerkiewnych na terenie Wielkiego Księstwa Litewskiego, odzyskanie przez Cerkiew dawnych praw i wolności oraz odbudowę dużej liczby cerkwi i monasterów. Chociaż literatura na temat Józefa Sołtana jest obszerna, pytanie, z jakiej rodziny Sołtanów pochodził metropolita, dotąd pozostawało bez odpowiedzi. Większość badaczy uważa, że Józef Sołtan, prawosławny biskup smoleński (1503-1507), następnie metropolita kijowski (1507-1521), był synem Sołtana Aleksandrowicza i Wasylissy Chreptowiczówny, bratem Aleksandra 
Sołtana ${ }^{1}$. W starszych opracowaniach (np. Ignacego Stebelskiego czy Jana Alojzego Kuleszy) hierarcha utożsamiany był ze stryjem Iwanem Aleksandrowiczem, a nawet przypisywano mu podwójne imię Jana (Iwana) i Józefa ${ }^{2}$. Głównym celem autora niniejszego artykułu jest próba rozstrzygnięcia sporu wokół pochodzenia rodowego metropolity Józefa Sołtana oraz wyjaśnienie kontrowersji wokół jego rzekomej sympatii do unii kościelnej.

Józefa Sołtana określano jako gorącego zwolennika unii. Koronnym dowodem miały być zapisy w Kronice Ławry Supraskiej, która została sporządzona w połowie XVIII wieku przez unickiego mnicha Mikołaja Radkiewicza. W opinii kronikarza fundatorzy monasteru pozostawali in sancta unione z Rzymem. Mikołaj Radkiewicz, a za nim wielu współczesnych badaczy, twierdził, że metropolita Józef Sołtan sympatyzował z unią i uznawał zwierzchność papieża. Według bazyliańskiego kronikarza za takim stanowiskiem przemawiały następujące argumenty: Józef Sołtan był wśród osób, które pisały do papieża w sprawie unii kościelnej, na prośbę wielkiego księcia Aleksandra Jagiellończyka metropolita przekonywał księżną Helenę Iwanówną do uznania jurysdykcji papieża, a jedna z kronik - „moskiewska” określała metropolitę kijowskiego Sołtana mianem „łacinnika”. Na podstawie tych argumentów Mikołaj Radkiewicz uzasadniał, że metropolita Józef Sołtan był unitą ${ }^{3}$.

${ }^{1}$ H. Lulewicz, Józef Soltan [w:] Polski Stownik Biograficzny, t. LX, z. 3, W. Konopczyński et al. (red.), Warszawa-Kraków 2001, s. 359-361.

${ }^{2}$ Por: I. Stebelski, Dwa Wielkie Światta na Horyzoncie Połockim z Cieniów Zakonnych Powstajace, czyli Żywoty SS. Panien y Matek Ewfrozyny y Parascewii, Zakonnic y Hegumeniy, Pod Ustawa S. O. Bazylego W. w Monastyrze S. Spasa za Połockiem żyjacych, z Chronologia y Przydatkiem Niektórych Stużacych do tego Pożytecznych Krajowych Wiadomości, z Rozmaitych Dziejopisow y Pism zebranych, przez X. W. Ignacego Stebelskiego Zakonu S. Bazylego W. Prowincyi Litew: Okazane, y za Pozwoleniem Zwierzchności do Druku Podane Roku Pańskiego 1781, tomik I. W Wilnie w Drukarni Bazylianskiey, Wilno 1781, s. 50; tenże, O Prześwietnej Familii JMść PP. Soltanów [w:] Ostatnie Stebelskiego prace $z$ autografu wydat, wstępem i przypisami objaśnit dr Władysław Seredyński, „Sciptores Rerum Polonicarum", t. IV, Kraków 1874, s. 373; J.A. Kulesza, Wiara prawostawna pismem świętym, soborami, Oycami SS. mianowicie greckiemi y historya kościelna przez X. Jana Aloyzego Kuleszę Societatis Jesu Theologa objaśniona, od przyiętey Unii Boga z czlowiekiem roku 1747 w Wilnie w drukarni Akademickiey SJ., Wilno 1747 , s. 183. Podobny pogląd wyraził A.L. Sołtan w Kronice żałobnej, T. Żychliński (red.), Poznań 1877, s. 411-415, i w artykule Aleksander Soltan. Szambelan Karola Zuchwatego i Kawaler Ztotego Runa, „Przegląd Poznański” 1862, t. XXXIII, s. 65-80.

${ }^{3}$ Arkheograficheskii sbornik dokumentov, otnosiashchikhsia k Istorii Severo-Zapadnoi Rusi, izdavaiemyi pri upravlenii Vilenskogo uchebnogo okruga, t. IX, Vil'no 1870, s. 10-12 (dalej: ASD). Pogląd taki wyraża między innymi J. Maroszek, Pogranicze Litwy i Korony w planach króla Zygmunta Augusta, Białystok 2000, s. 116, 126-138, 141-142. Na błędy w interpretacji dokumentów historycznych przez J. Maroszka zwracali uwagę między innymi: A. Mironowicz, Największa fundacja Aleksandra Chodkiewicza. Spór o charakter fundacji [w:] Władza i prestiz. Magnateria Rzeczypospolitej w XVI-XVIII wieku, J. Urwanowicz (red.), Białystok 2003, s. 529-550; L.L. Shchaviskaia, Literaturnaia ku'tura belorusov Podliash'ia XV-XIX vv., Knizhnyie sobraniia Suprasl'skogo Blagoveshchenskogo monastyria, Minsk 1998, s. 17-79. 
Przedstawione wyżej argumenty, cytowane przez późniejszych badaczy, nie znajdują uzasadnienia źródłowego. Metropolita Józef Sołtan, był w literaturze mylony ze swym poprzednikiem Józefem Bułharynowiczem - piastującym funkcję metropolity kijowskiego w latach 1498-1501. W źródłach pochodzących z przełomu XV i XVI wieku przy godności metropolity nie podawano nazwiska, a jedynie wymieniono imię biskupa. Takie zapisy spowodowały, że działania prounijne Józefa Bułharynowicza często przypisywano metropolicie Józefowi Sołtanowi. Dodatkowym czynnikiem powodującym mylenie obu postaci był fakt piastowania przez nich funkcji na katedrze smoleńskiej.

Nieprawdziwa jest informacja, że na początku XVI wieku Józef Sołtan wstąpił do monasteru Trójcy Świętej w Słucku i wyposażył słucką cerkiew soborną w naczynia liturgiczne oraz liczne księgi przywiezione przez niego z Konstantynopola. W tym czasie Józef Sołtan uczestniczył w walkach po stronie wojsk litewskich podczas oblężenia Smoleńska i nie mógł przebywać w Słucku czy w Konstantynopolu. Rok wcześniej król polecił go na władyctwo smoleńskie 5 . Jego kandydaturę poparli księżna Helena Iwanówna i książę Konstanty Ostrogski, co pozwoliło mu objąć w 1503 roku katedrę smoleńską ${ }^{6}$. Za bezpodstawne należy uznać panujące w literaturze naukowej przekonanie, że Józef Sołtan był potomkiem marszałka hospodarskiego Aleksandra Sołtana (1440-1495). Historycy wskazują na tego, który podpisał się pod unijnym posłaniem do Sykstusa IV w 1476 roku$^{7}$. Sołtan Aleksandrowicz, którego podpis widnieje pod posłaniem do papieża w 1493 roku, za zasługi dla wielkiego księcia Aleksandra Jagiellończyka otrzymał dobra w powiecie słonimskim z Żyrowicami. Tam też ufundował pierwszą cerkiew na miejscu objawienia się cudownej ikony Matki Bożej ${ }^{8}$.

${ }^{4}$ Mitropolit Makarii, Istoriia Russkoi Tserkvi, t. IX, Sankt-Peterburg 1879, s. 165; K. Chodynicki, Kościót prawosławny a Rzeczypospolita Polska, Warszawa 1934, s. 120-121; A. Mironowicz, Kościót prawosławny w dziejach dawnej Rzeczypospolitej, Białystok 2001, s. 320, 325. O przywiązaniu Józefa Sołtana do prawosławia świadczy fakt, że nuncjusz papieski Zachariasz Forreri wysłany przez papieża Leona X (1513-1521) w 1521 r. w celu omówienia kanonizacji św. Kazimierza do Wilna nazwał hierachę Józefa Sołtana „wielkim schizmatykiem”. Por. J. Daniłowicz, Skarbiec dyplomów papieskich, ksiązęcych, uchwat narodowych, postanowień różnych władz i urzędów postugujących do krytycznego wyjaśnienia dziejów Litwy, Rusi Litewskiej i ościennych innych krajów, t. II, Wilno 1862, s. 263-265.

${ }^{5}$ Według metropolity Makarego i A. Martosa Józef Sołtan został „nareczennym” biskupem smoleńskim już w 1502 r., por.: Mitropolit Makarii, Istoriia Russkoi Tserkvi, kn. V, Moskva 1996, s. 99; Afanasii (Martos), Belarus v istoricheskoi, gosudarstvennoi i tserkovnoi zhizni, Buenos-Aires 1966, s. 70. Biskup „nareczenny" to hierarcha wybrany, mianowany, ale nie konsekrowany.

${ }^{6}$ „Vestnik Zapadnoi Rossii”, g. V, kn. 7, t. III, otd. 2, Vil'no 1866/1867, s. 1-6; I. Stebelski, O Prześwietnej Familii..., op. cit., s. 377-381; E. Tserenteli, Elena Ioannovna, velikaia kniaginia litovskaia, russkaia, koroleva pol'skaia, Sankt-Peterburg 1899, s. 301; A. Mironowicz, Powstanie monasteru supraskiego, „Białostockie Teki Historyczne” 2012, nr 10, s. 31.

7 J. Fijałek, Kopiarz rzymski, „Archiwum Komisji Historycznej”, seria II, t. I, Kraków 1923, s. 75; L. Korczak, Litewska Rada wielkoksiążęca w XV wieku, Kraków 1998, s. 98.

${ }^{8}$ A. Mironowicz, Jozafat Dubieniecki. Historia cudownego obrazu żyrowickiego, „Zeszyty Naukowe KUL" 1994, R. XXXIV, nr 1-2 (133-134), s. 213-232. A. Beletskii, Rodoproiskhozhdeniie zapadnoruskago mitropolita Iosifa II Soltana, Vil'no 1895, s. 3-30; A. Łapiński, Zygmunt Stary a Kościót prawosławny, Warszawa 1937, s. 15. Sołtanowie z tej linii byli fundatorami kilku cerkwi i monasterów, w tym Narodzenia NMP w Trokach (Mitropolit Makarii, Istoriia Russkoi Tserkvi, kn. V, op. cit., s. 123). Prawdopodobnie wnuk Aleksandra, Iwan Andrzejewicz Sołtan, otrzymał 27 października 1526 r. opiekę 
Spróbujmy odpowiedzieć na pytanie, z jaką gałęzią rodową Sołtanów należy łączyć postać metropolity Józefa. Znany badacz dziejów Cerkwi metropolita Makary (Michał Pietrowicz Bułhakow) uważał, iż urodził się on około 1460 roku i był synem Sołtana Aleksandrowicza i Wasilissy Tyszkiewiczówny ${ }^{9}$. Matka pozostawiła synowi dwie wsie: Usiaż i Kołodzież ${ }^{10}$. Metropolita Makary łączył ową postać z rodem Sołtanów, który ufundował monaster w Żyrowicach. Tymczasem nowe dokumenty rzucają nieco inne światło na pochodzenie rodowe Józefa Sołtana. W supraskim Subbotniku ili Pominniku znajdują się imiona osób z rodziny arcybiskupa Józefa Sołtana ${ }^{11}$. Nie wszystkie imiona postaci wymienionych w źródle udało się ustalić, ale już wstępne porównanie ze znanymi nam gałęziami rodowymi Sołtanów wskazują, że metropolita Józef Sołtan pochodził z innej linii aniżeli wcześniej przypuszczano. Przeanalizujmy więc zapis z supraskiego Subbotnika ili Pominnika ${ }^{12}$ :

nad monasterem Narodzenia NMP w Trokach (Af. Jarushevich, Revnitel' pravoslaviia, kniaz' Konstantin Ivanovich Ostrozhskii (1461-1530) i pravoslavnaia Litovskaia Rus'v iego vremia, Smolensk 1896, s. 179-180; Mitropolit Makarii, Istoriia Russkoi Tserkvi, kn. V, op. cit., s. 132) oraz nad cerkwią św. Jana Chrzciciela w Wilnie (Mitropolit Makarii, Istoriia Russkoi Tserkvi, kn. V, op. cit., s. 158). Sołtanowie byli fundatorami monasteru św. Szymona Słupnika w Brześciu. Z tego powodu w $1546 \mathrm{r}$. monaster był nazywany „monasterem pana Aleksandra Sołtanowicza”. Do klasztoru, podobnie jak w przypadku monasteru Narodzenia NMP, należeli „ludzie cerkiewni”. Pozostawali oni pod jurysdykcją rodziny Sołtanów i zwolnieni byli z podatku „kopszczyzny”, w zamian jednak musieli płacić czynsz na rzecz klasztoru. Monasterowi św. Szymona Słupnika fundatorzy zapisali wieś Murawiec, położoną w województwie brzeskim. $A S D$, t. XI, Vil'no 1890, s. XVIII. Sołtanowie byli też opiekunami prawosławnych cerkwi św. Trójcy i św. Mikołaja w Wilnie oraz monasteru Narodzenia NMP w Trokach. Por. I. Stebelski, O Prześwietnej Familii..., op. cit., s. 374-377.

${ }^{9}$ Mitropolit Makarii, Istoriia Russkoi Tserkvi, kn. V, op. cit., s. 106; „Kievskiie Eparkhial'nyie Vedomosti” 1873, otd. II, s. 315; Af. Jarushevich, op. cit., s. 113, przyp. 264.

${ }^{10}$ Obie wsie znajdowały się przy drodze od Łohojska do Mińska. Pierwotnie wsie wchodziły w skład dóbr rodowych metropolity Józefa Sołtana, a następnie stały się uposażeniem metropolitów kijowskich (prawosławnych a później unickich), Słownik Geograficzny Królestwa Polskiego i innych krajów słowiańskich, F. Sulimierski, B. Chlebowski, W. Walewski (red.), t. IV, Warszawa 1883, s. 281; t. XII, Warszawa 1882 , s. 838.

${ }^{11}$ A. Mironowicz, Subotnik ili Pominnik monasteru supraskiego, Białystok 2015, s. 90-94. Obszerne fragmenty rękopisu zostały opublikowane przez Wileńską Komisję Archeograficzną w $1870 \mathrm{r}$. w Wilnie, $A S D$, t. IX, Vil'no 1870, s. 454-459. Fragmenty supraskiego manuskryptu opublikował również archimandryta Modest w 1867 r. (Modest [Strel'bitskii], Suprasl'skii Blagoveshchenskii monastyr', „Vestnik Zapadnoi Rossii. Istoriko-literaturnyi zhurnal” 1867, g. V, kn. 6, t. II, otd. 2, s. 128-131) i biskup grodzieński Nikanor Kamieński w 1904 r. (E.N., Staryi sinodik Suprasl'skogo monastyria, „Grodnenskiie Eparkhial'nyie Vedomosti” 1904, № 27, s. 788-799).

${ }^{12}$ Pomianiki są to spisy nieżyjących osób, sporządzane przez duchownych przy cerkwiach i w monasterach. Wykorzystywano je podczas nabożeństwa, modląc się za dusze zmarłych zapisanych w pomianiku. Pomenyk Sofiyi Kyyivs'koyi: publikatsiya rukopysnoyi pam'yatky druhoyi Polovynykhviii-pershoyi chverti XIX st., uporyadok ta vstupni statti O. Prokop'yuk, Kyiv 2004 (Nekropolistyka v Ukrayini, vyp. 3(8)), s. 5-15; A. Mironowicz, Subotnik ili Pominnik monasteru supraskiego, op. cit., s. 41-44. 
Rod Buakov Iakova Davidovicha Soltanov ${ }^{13}$. Pomeni Gospodi dushi usopshikh rab svoikh. Preosviashchennago arkhiepiskopa Iosifa ${ }^{14}$, Lazara ${ }^{15}$, Konona ${ }^{16}$, Dawida ${ }^{17}$, Ignatia ${ }^{18}$, Aleksandra $^{19}$, Uvara, Isakia, Antipy, Ioana ${ }^{20}$, Iakova ${ }^{21}$, Mikhaila ${ }^{22}$, Guria $^{23}$, Aleksandra ${ }^{24}$, Ioana $^{25}$, Petra ${ }^{26}$, Romana ${ }^{27}$, Ioana ${ }^{28}$, Marii ${ }^{29}$, Eleny, Matfeia, Sidora, Fedora ${ }^{30}$, Ioana (Laptia ${ }^{31}$, Aleksandra $^{32}$, Ioana ${ }^{33}$, Mikhaila ${ }^{34}$, Georgia ${ }^{35}$, Mikhaila ${ }^{36}$, Ivana ${ }^{37}$, Fedora $^{38}$, Grigoria ${ }^{39}$, Stefa-

${ }_{13}$ Jakub Pokalewski, syn Dawida Welawskiego Sołtana, zwanego Bułhak, zm. po 1470 r.

${ }^{14}$ Józef Sołtan (właściwie: Eliasz Sołtanowicz), władyka smoleński (1503-1508), metropolita kijowski (1507-1521).

${ }^{15}$ Łazarz, bojar, właściciel Bogorodicy. Sołtan Ondriew, syn Łazarza, bojara w powiecie bogorodickim w Księstwie Moskiewskim.

${ }^{16}$ Konon Sołtan, syn Bułhaka, bojara owruckiego.

${ }_{17}$ Dawid Sołtan, syn Bułhaka (przed 1392-po 1470), książę kijowski (1455-1470).

18 Ihnat Sołtan Bułhak, walczył w bitwie z Tatarami nad Worsklą (1399), podpisał unię polsko-litewską w $1401 \mathrm{r}$.

19 Aleksander Jurewicz Sołtan, bojarzyn ruski (1400-1454), podskarbi litewski (1443-1454).

${ }^{20}$ Iwaszko - Iwan Aleksandrowicz Sołtan, marszałek hospodarski przed 1493 r., właściciel Żyrowic.

${ }^{21}$ Jakub - Bułhak, był bojarem owruckim z wojska Aleksego Mansura-Kijatowicza Glińskiego, który w 1397 r. ochrzcił się w Kijowie z imieniem Jakub. Jakub Bułhak przeszedł na służbę wielkiego księcia litewskiego Witolda i otrzymał od niego Welawsk.

${ }^{22}$ Michał, starszy brat metropolity Józefa Sołtana, był synem Sołtana Aleksandrowicza i Wasylisy Tyszkiewiczówny.

${ }^{23}$ Gury - Guriasz Sołtan, właściciel dóbr koło Łohojska.

${ }^{24}$ Aleksander Aleksandrowicz Sołtan, ur. po 1478 r., marszałek nadworny litewski (1515-1541), dziedzic Żyrowic, od 1549 r. był właścicielem Wołczyna w powiecie brzeskim, Żyrowic w powiecie słonimskim, Nieświeża w powiecie nowogródzkim; żona - ks. Bujnicka, córka Lwa i Teodozji Worotyńskiej, druga - Teodora Hłazynówna, trzecia - Wasylisa Chreptowicz.

${ }^{25}$ Iwan, syn Aleksandra Aleksandrowicza Sołtana i Teodory Hłazynówny, od 1566 r. starosta ostryński, marszałek nadworny litewski, dziedzic Żyrowic, zm. po 1575 r.

${ }^{26}$ Piotr, bojar łohojski na służbie ks. Aleksandra Czartoryskiego, a potem Michała Sołtana.

${ }^{27}$ Roman, syn Tymszy. Od Romana pochodzą Bułhakowie. Walczył w bitwie z Tatarami nad Worsklą (1399).

28 Jan, brat Piotra i Romana.

${ }^{29}$ Maria Wasylewna Sołomerecka, właścicielka i ktitorka monasteru żyrowickiego, druga żona Iwana Aleksandrowicza Sołtana, starosty ostryńskiego.

${ }^{30}$ Fiodor (Fedko) Gorłowicz Sołtan, bojar owrucki po $1492 \mathrm{r}$.

31 Jan Litawor Chreptowicz, podskarbi nadworny (1482-1492), marszałek hospodarski (1492-1500).

32 Aleksander, syn Aleksandra Aleksandrowicza Sołtana i Teodory Hłazynówny (córki Aleksandra Bazylewicza Hłaziny, starosty smoleńskiego), właściciel Bojnicz i Oreszewa w powiecie oszmiańskim.

${ }^{33}$ Iwan Wasylewicz z żoną Oleną Fedorową, bojar (1556), starosta rzeczycki. Iwan Wasylewicz Sołtan, dzierżawca ostryński, marszałek dworski (1572-1579).

${ }^{34}$ Michał, syn Sołtana Aleksandrowicza, brat Iwana, Aleksandra i Grzegorza, chorąży wołyński (1529-1544).

${ }^{35}$ Jerzy Aleksandrowicz Sołtan Poczapowski (ok. 1440-1490), brat Iwana, Andrzeja, Sołtana i Michała.

${ }^{36}$ Michał Aleksandrowicz Sołtan z Zahorowa (ok. 1440-1490), brat Jerzego, Iwana, Andrzeja i Sołtana.

${ }^{37}$ Iwan Aleksandrowicz Sołtan, podskarbi ziemski, zm. po 1486 r., syn Aleksandra Juriewicza.

${ }^{38}$ Fiodor (Teodor) Sołtan (1510-1576), bojar ziemi kijowskiej.

${ }^{39}$ Hrehory (Hryńko), syn Sołtana Aleksandrowicza Sołtana, brat Eliasza i Michała. 
na, Ioana (Bulkag) $)^{40}$, Petra $^{41}$, Vasilia ${ }^{42}$, Iosifa, Amosa, Grigoria ${ }^{43}$, Feodosia, Fedora ${ }^{44}$, Iakova, Antona, Vasilia ${ }^{45}$, Feodora ${ }^{46}$, Ucherlity, Uliany, Domny, Evfimii, Mariii ${ }^{47}$, Vasilia ${ }^{48}$, Evfimii, Davida $^{49}$, Marii ${ }^{50}$, Marii ${ }^{51}$, Iuliany ${ }^{52}$, Marfy, Marii, Nikity, Terentia ${ }^{53}$, Feodora ${ }^{54}$, Ioakima, Glikerii, Aleksiea, Ogafii, Akiliny, Ieremia, Feodora ${ }^{55}$, Simeona ${ }^{56}$, Aleksiea, Anny ${ }^{57}$, Eleny, Eleny, Marii, Antonidy, Eleny ${ }^{58}$, Evsevia, Stefana ${ }^{59}$, Nikity, Ioana ${ }^{60}$, Feodota ${ }^{61}$, Georgia ${ }^{62}$, Stefana $^{63}$, Varvary ${ }^{64}$, Nastasii ${ }^{65}$, Grigoria ${ }^{66}$, Vasilia ${ }^{67}$, Pankrata, Feodora ${ }^{68}$, Anny ${ }^{69}$, Fomy,

${ }^{40}$ Iwan Bułhak Sołtan, bojar z ziemi kijowskiej (1552-1558), albo Iwan Sołtan, (1590-1635), sędzia rzeczycki, starosta propojski.

${ }^{41}$ Piotr, syn Iwana Bułhaka Sołtana zw. Lewkowski (1576-1632).

42 Wasyl Jurewicz Bułhak Sołtan, namiestnik jarosławski, bojar (1509-1530).

${ }^{43}$ Hrehory (Hryko) Iwanowicz, bojar w powiecie owruckim (1492-1502), pisarz wielkiej ks. Heleny Iwanówny.

${ }^{44}$ Fiodor Sołtan, dworzanin hospodarski (1549-1573), pisarz włodzimierski.

45 Wasyl Sołtan, zm. w 1620 r., mąż Anny Pogirskiej.

${ }^{46}$ Fiodor Sołtan Buciatycki, herbu Syrokomla, chorąży kijowski, pisarz włodzimierski (1566-1593).

${ }^{47}$ Marina, siostra metropolity Józefa Sołtana, żona Wasylego Hornostaja.

${ }^{48}$ Wasyl Hornostaj, mąż Mariny Sołtan.

49 Dawid Iwanowicz Sołtan, właściciel Murawki i ktitor cerkwi św. Symeona w Murawce, starosta ostryński (zm. 1578), syn Iwana Sołtana i Marii Wasylewnej Sołomereckiej.

${ }^{50}$ Maria, żona syna Dawida Jarosława, starosty ostryńskiego, właściciela Wołczyna w powiecie brzeskim, zm. po $1593 \mathrm{r}$.

${ }^{51}$ Maria, córka Dawida Iwanowicza Sołtana, dziedzica połowy Żyrowic.

52 Julianna, dwórka wielkiej księżnej Heleny Iwanównej.

${ }_{53}$ Hieronim Sołtan (1550-1621), syn Iwana Sołtana i Marii Wasylewnej Sołomereckiej.

${ }^{54}$ Fiodor (Teodor) Sołtan, podstarości rzeczycki, żona Aleksandra Wietczana.

55 Teodor Bohdanowicz Sołtan, syn Bohdana, pisarza ziemskiego włodzimierskiego.

${ }^{56}$ Semen Kurcewicz Sołtan, protoplasta rodu Możarowskich i Możajskich, właściciel Staroduba, Czernihowa i Homla.

57 Anna Sołtan, siostra metropolity Józefa Sołtana, żona ks. Aleksandra Czartoryskiego.

${ }^{58}$ Helena Kurcewicz, żona Semena Iwanowicza Możajskiego, teściowa Anny Sołtan, matka męża Anny, Hawryły Możajskiego (1484-1534).

${ }^{59}$ Stefan, duchowny wileńskiej cerkwi Zmartwychwstania Pańskiego, spowiednik Iwana Andrzejewicza Sołtana.

${ }^{60}$ Iwan Andrzejewicz Sołtan (ok. 1470-1554), podskarbi nadworny litewski (1509-1554), namiestnik dubiński (1507-1508), namiestnik mejszagolski, żona - Bohdana Fedorowna Czetwertyńska.

${ }^{61}$ Fiedot (Fiodor) Andrzej, podskarbi nadworny (1504-1554), ojciec Iwana Andrzejewicza Sołtana, opiekuna monasteru w Trokach, fundator cerkwi św. Jana Chrzciciela w Wilnie jako kaplicy rodowej Sołtanów (1554), opiekun monasteru żyrowickiego.

${ }^{62}$ Jerzy Sołtan (1590-1635), syn Iwana Sołtana, sędziego ziemskiego rzeczyckiego, starosty propojskiego i Anny Szorc.

${ }^{63}$ Stefan Możajski Sołtan, syn Iwana Możajskiego Sołtana i Praksedy Masłowskiej.

${ }^{64}$ Barbara Gałeczkowska, żona Jarosława Iwanowicza Sołtana, właściciela połowy Żyrowic.

${ }_{65}$ Nastazja Iwanówna Sołtanowa, żona Jana Kgrekowa, ziemianina brzeskiego.

${ }^{66}$ Hrehory, syn Iwana Andrzejewicza Sołtana i Bohdany Fedorówny Czetwertyńskiej.

${ }^{67}$ Wasyl Iwanowicz Puzyna (Hłuszonok), syn Iwana Iwanowicza, właściciel ziem Nosowo w powiecie mielnickim, zm. w 1521 r., mąż Anny Hrynkiewnej Sołtan.

${ }^{68}$ Fiodor Steckowicz Sołtan, bojar owrucki, zm. po 1576 r.

${ }^{69}$ Anna Hrynkiewna Sołtan, żona księcia Wasyla Iwanowicza Puzyny, następnie Juchny Wańkowicza. 
Anny $^{70}$, Marii, Nestora, Gavriila ${ }^{71}$, Nastasii ${ }^{72}$, Kirila ${ }^{73}$, Ioana ${ }^{74}$, Filippa, Anny ${ }^{75}$, Feodora ${ }^{76}$, Grigoria $^{77}$, Akiliny, Dementia, Glikerii, Vasilia ${ }^{78}$, Anny $^{79}$, Eleny, Ioana ${ }^{80}$, Georgia $^{81}$, Samoila ${ }^{82}$, Marii, Eliferia, Feodosiiu ${ }^{83}$, Grigoria ${ }^{84}$, Deomida ${ }^{85}$.

Kluczowe do rozwiązania problemu są tu imiona najbliższych członków rodziny metropolity Józefa Sołtana, protoplastów rodu: Jakuba i Dawida Sołtanów. Jeden z nich to Jakub Pokalewski, syn Dawida Welawskiego Sołtana, zwany Bułhakiem, zmarły po 1470 roku. Drugi z wymienionych to Dawid Sołtan urodzony przed 1392 rokiem, a zmarły po 1470 roku, bojar ziemi owruczskiej, właściciel Welawska i Stawka w ziemi turowskiej. Od Dawida pochodzą Jelcewie i Jelcowie. Jakub i Dawid są protoplastami tej linii Sołtanów. W wykazie osób z rodu metropolity Józefa Sołtana znajduje się wiele imion niesłowiańskich bądź starozakonnych. Większość z wymienionych imion nie występuje w litewsko-nowogródzkiej linii rodowej Sołtanów. Nawet jeżeli uwzględnimy to, że do supraskiego Subbotnika ili Pominnika wpisano osoby luźno powiązane z rodem, na przykład rodziców małżonek lub wybranych postaci spokrewnionych z Sołtanami, to nie ma pośród nich charakterystycznych imion dla przypisywanej w literaturze naukowej podlaskiej czy żyrowickiej (nowogródzkiej) linii rodowej. Szczegółowa analiza imion i porównanie ich z genealogią innych gałęzi rodziny Sołtanów świadczą o bliskim pokrewieństwie z linią łohojską i owrucką. Imiona Akiliny, Dementia, Glikerii, Eliferia, Deomida wskazują na to, że wśród kuzynów metropolity byli przedstawiciele linii ormiańskiej Sołtanów, mocno zakorzenionych w Kijowie ${ }^{86}$. Od nich wywodziło się wiele rodzin ormiańskich

70 Anna, siostra Iwana Andrzejewicza Sołtana, zm. w 1554 r.

${ }^{71}$ Gabriel Semenowicz Możorowski (1486-1532), mąż Anny Andrzejewnej Sołtan, bratanicy metropolity Józefa.

72 Nastazja, siostra Iwana Andrzejewicza Sołtana, zm. w 1554 r.

73 Cyryl Sołtan, brat Iwana Sołtana z linii ormiańskiej.

${ }^{74}$ Iwan Sołtan, ur. 1520 r. Pochodził z rodziny ormiańskiej z Kijowa, był posiadaczem Sołtanówki Wielkiej i Małej, poseł na sejmy: 1569, 1572, 1578, $1582 \mathrm{r}$.

75 Anna, żona Fiodora Steckowicza Sołtana, bojara owruckiego z linii ormiańskiej.

${ }^{76}$ Fiodor Sołtan, syn Iwana Sołtana z linii ormiańskiej.

77 Hrehory Szyka Sołtan, bojar owrucki, brat Fiodora Sołtana.

${ }_{78}$ Wasyl Możajski, ks. werejski, syn Michała Andrzejewicza Możajskiego, właściciel Briańska.

${ }^{79}$ Anna, córka Daniela Dawidowicza Sołtana, właściciela Żyrowic.

${ }^{80}$ Iwan Aleksandrowicz Sołtan, bratanek Iwana Andrzejewicza Sołtana, właściciel dworu w Wilnie, pełnomocnik ks. Barbary Sołomereckiej.

${ }^{81}$ Jerzy Sołtan, bojar ziemi owruckiej.

${ }^{82}$ Samuel Wasylewicz Sołtan, burmistrz łucki do 1621 r., mieszczanin, członek bractwa cerkiewnego, który w testamencie z 21 czerwca 1621 r. zapisał cały swój majątek na rzecz cerkwi Podwyższenia św. Krzyża w Łucku.

${ }_{83}$ Teodora Sołtan, żona Stanisława Korybskiego, syna Wojciecha Korybskiego.

${ }^{84}$ Hrehory Bohuszewicz Sołtan.

${ }^{85}$ Damian Sołtan, syn Iwana Sołtana, wojskiego rzeczyckiego, zm. ok. 1621 r.

${ }^{86}$ Nazwisko Sołtanów, Sołtanowiczów było popularne na ziemiach ruskich. Sołtanowie ormiańscy pochodzili od książąt z Armenii. Wielu Ormian tępionych w swej ojczyźnie od końca XIII w. wyjeżdżało za granicę, osiedlając się wśród Słowian i na terytorium księstw rumuńskich. Ormiania osiedlali się w Rzeczypospolitej głównie w w województwach południowowschodnich. Za czasów Kazimierza 
(Abgarowicze, Wartanowicze, Zachayasiewicze, Tegdorowicze i Sołtanowie). Ci ostatni przenieśli się na Polesiu i Litwie dali początek wielu rodom o nazwisku Sołtan. Większość z nich legitymowało się herbem Korczak, a potem Abgarowicz ${ }^{87}$.

Rodzina Sołtanów była powiązana z Łuckiem i Włodzimierzem Wołyńskim. W supraskim Subbotniku ili Pominniku znalazły się imiona osób, które zamieszkały w tych grodach. Między innymi jest tam wymieniony mieszczanin łucki Samuel Wasylewicz Sołtan, który 21 czerwca 1621 roku zapisał cały swój majątek na rzecz bractwa przy cerkwi Podniesienia Świętego Krzyża w Łucku i na utrzymanie przy nim przytułku i szkoły ${ }^{88}$. W wykazie uwzględniony został również namiestnik kijowski z 1605 roku Aleksander Sołtan.

W wyjaśnieniu pochodzenia rodowego metropolity Józefa Sołtana pomaga dokument z Metryki Litewskiej dotyczący potwierdzenia przez Aleksandra Jagiellończyka 29 sierpnia 1496 roku księciu Semenowi Aleksandrowiczowi Czartoryskiemu ${ }^{89}$ praw do miejscowości Łohojsk, Ostaszyn koło Ławryszewa, Sporow koło Zdzitowa, Kamieniec, Haniewicze na Litwie i innych wsi na wieczność. Dobra te wcześniej zostały nadane przez Kazimierza Jagiellończyka księciu Aleksandrowi Wasylewiczowi Czartoryskiemu, ojcu Semena. Aleksander Wasylewicz Czartoryski, były książę pskowski (1443-1447, 1456-1460) i nowogrodzki (1447-1455), powrócił na Litwę po 1460 roku. Jego pobyt na terenie Księstwa Moskiewskiego wiązał się z jego udziałem w zabójstwie księcia Świdrygiełły. Po powrocie księcia Aleksandra Czartoryskiego z Rusi Moskiewskiej na Litwę król Kazimierz Jagiellończyk nadał mu w 1460 roku Łohojsk, Ostaszyn, Sporów i Kamieniec ${ }^{90}$. W dokumencie z 29 sierpnia 1496 roku wymienia się Sołtanów zamieszkałych koło Łohojska w dobrach książąt Czartoryskich. Książę Aleksander Czartoryski za zgodą króla potwierdził Sołtanom prawo do posiadanych przez nich dóbr. Z kolei Semen Aleksandrowicz Czartoryski

Wielkiego na Rusi Halickiej przybyła znaczna liczba emigrantów ormiańskich. W miastach przybysze ormiańscy zajmowali się handlem i stanowili główną siłę finansową w miastach. Nazwiska i imiona Ormian na początku brzmiały oryginalnie w Polsce, albowiem syn przyjmował nazwisko po imieniu ojca. $\mathrm{Z}$ tego powodu wiele rodzin ormiańskich zmieniło swoje nazwiska, mimo że pochodzili od tego samego przodka. Między innymi Ormianie przybierać zaczęli końcówki nazwisk słowiańskich i w ten sposób nazwiska te nabierały formę familii litewskich, polskich czy ruskich. Ormiańska gałąź rodziny Sołtanów, która uprzednio mieszkała w Kijowie, w XVII w. przeniosła się na Wołoszczyznę, gdzie uzyskała szlachectwo i liczne dobra. Niektórzy z tego rodu przyjęli nazwisko Abgarowicze.

${ }^{87}$ Ormiańskie pochodzenie posiadali: Awakowie, późniejsi Wakowscy, Seferowicze albo Szadbeje i Krzysztofowicze. Ważną rolę wśród rodzin ormiańskich odgrywał kupiec kijowski - Abgarowicz Sołtan (brat Teodor należał do stanu rycerskiego). Sołtanowie pochodzili również z rodzin tatarskich, z których Aleksander już w połowie XV w. przyjął prawosławie. Por. Herbarz rodzin tatarskich w Polsce, St. Dziadulewicz (opr.), Wilno 1929, s. 437-438.

${ }^{88}$ Arkhiv Jugo-Zapadnoi Rossii, izdavaiemyi Vremennoju komissiieju dlia razbora drevnikh aktov, vysochaishe uchrezhdennoju pri Kiievskom voiennom, Podol'skom i Volynskom general-gubernatore (dalej: AJuZR), cz. 1, t. VI: Akty o tserkovno-religioznykh otnosheniiakh v Jugo-Zapadnoi Rusi (13221648 g.), Kiev 1883, nr 201.

${ }^{89}$ S.M. Kuczyński, Czartoryski Semen Aleksandrowicz [w:] Polski Stownik Biograficzny, t. IV, W. Konopczyński et al. (red.), Kraków 1938, s. 296-297.

${ }^{90}$ Akty, otnosiashchiiesia k istorii Jugo-Zapadnoi Rossii, t. I, Sankt-Peterburg 1863, s. 15; J. Wolff, Kniaziowie litewsko-ruscy od końca czternastego wieku, Warszawa 1895, s. 20; S.M. Kuczyński, op. cit., s. 271. 
zwolnił bojarów Sołtanów ze wszelkich powinności na rzecz właściciela Łohojska, a zwłaszcza ze służby wojskowej. Książę pozwolił najstarszemu synowi Sołtana Aleksandrowicza i jego braciom na swobodny wybór służby u dowolnego księcia. W ten sposób książę Semen Czartoryski wpłynął na dalsze losy rodziny Sołtanów.

Do czasu, kiedy Sołtanowie byli bojarami książąt Czartoryskich, ich majątki stanowiły część dóbr łohojskich. Gdy Sołtanowie przeszli na służbę wielkoksiążęcą, ich dobra zostały wyodrębnione $\mathrm{z}$ dóbr łohojskich i stały się samodzielnym kluczem z ,wsim prawom i panstwom"91. Uzyskując niezależny status, Sołtanowie zostali przyjęci na służbę hospodarską, która zapewniała im bezpieczny byt, ochronę przez zakusami lokalnych książąt na ich majątki i nowe możliwości awansu. Książęta litewscy chętnie przyjmowali na służbę bojarów, zwłaszcza w sytuacji zagrożenia granicy wschodniej ze strony moskiewskiej. Hospodar potwierdzał będącym u niego na służbie bojarom wszelkie prawa do posiadanych przez nich majątków. Książę Aleksander Jagiellończyk przyjął na służbę Sołtanów już po śmierci ich ojca - Sołtana Aleksandrowicza. Ostatecznie w końcu 1496 roku hospodarskimi bojarami zostali trzej jego synowie: Michał, Eliasz i Hryńko. Przejście na służbę hospodarską było dla Sołtanowiczów bardzo korzystne. Wkrótce otrzymali oni od wielkiego księcia Aleksandra Jagiellończyka wieś z sianożęciami nad rzeką Hainą, w powiecie łohojskim, z trzema rodzinami tatarskimi na służbie. Oprócz tego Aleksander Jagiellończyk podarował im trzy kolejne rodziny: „Iwana, Tereszkę i ich bratanków Jakowych, dzieci Osipowiczów"92. Książę Semen Czartoryski, wykorzystując sytuację, że bojarowie pozostawali przez cały rok poza swymi dobrami, samowolnie w 1499 roku zajął ich pole i odebrał nadane przez wielkiego księcia trzy rodziny. W odpowiedzi na skargę Sołtanów książę Aleksander Jagiellończyk nakazał zwrot odebranych im ludzi i ziem.

Najstarszym z bojarów Sołtanów będących na służbie hospodarskiej był Michał, zmarły bezdzietnie po 1496 roku. Najmłodszy zaś Hrynko był żonaty i miał córkę Annę, która wyszła za mąż za dworzanina Juchnę Wańkowicza. Według Józefa Wolffa Anna Sołtan wyszła najpierw za mąż za Wasyla Puzynę, a dopiero później za Juchnę Wańkowicza. Wasyl Iwanowicz Puzyna, pochodzący z powiatu łohojskiego, od 1513 roku właściciel dóbr Nosowo w powiecie mielnickim otrzymanych po księżnej Helenie, mąż Anny Hrynkiewnej Sołtan, syn Iwana Iwanowicza, zmarł w 1521 roku. Juchno Wańkowicz był więc drugim mężem Anny Sołtan. Oprócz Nosowa posiadała ona jeszcze wieś Seliszcze pod Łohojskiem, po pierwszym mężu ${ }^{93}$. W źródłach nie sposób odnaleźć żadnych informacji o rodzinie Eliasza, brata Michała i Hryńka Sołtanów. Z późniejszych sporów majątkowych wynika, że nie miał ani żony ani dzieci.

Eliasz Sołtan to prawdopodobnie późniejszy metropolita Józef Sołtan, który pozostawał na służbie hospodarskiej i brał udział w wojnie litewsko-moskiewskiej w latach 1501-1503, podczas której wykazał się wielką odwagą i lojalnością wobec panującego. Według ustaleń Hieronima Grali przywilej hospodarski został mu

91 M.K. Ljubavskii, Oblastnoie deleniie i mestnoie samoupravleniie Litovsko-russkogo gosudarstva, Moskva 1892, s. 615, 617.

92 A. Beletskii, op. cit., s. 24.

93 J. Wolff, op. cit., s. 72, 408. 
nadany we wrześniu 1503 roku ${ }^{94}$. Józef Sołtan, od 1502 roku jako biskup nominat, odegrał ważną rolę w odparciu wojsk moskiewskich pod Smoleńskiem ${ }^{95}$. Jego dobra rodzinne zostały w pobliżu Smoleńska kompletnie zniszczone, a większość uposażenia biskupiego pozostała po stronie moskiewskiej. Aleksander Jagiellończyk po zawarciu rozejmu pragnął zrekompensować mu poniesione szkody i przywilejem z 15 września 1503 roku nadał na wieczność we włości suraskiej na Podlasiu sześć „służb ludu" ${ }^{\circ}$. Biskup smoleński zdawał sobie sprawę z rangi ufundowanego monasteru supraskiego. Kiedy Józef Sołtan. za zasługi w wojnie z Moskwą oraz utracone majątki, otrzymał w 1504 roku od króla Aleksandra, sześć służb kmiecych we włości suraskiej - przekazał je monasterowi ${ }^{97}$. Przekazanie ziem nastąpiło 11 maja 1506 roku, kiedy Józef Sołtan wszedł w bezpośrednie relacje z Aleksandrem Chodkiewi$\mathrm{czem}^{98}$. Przez oddanie majątków w powiecie bielskim patriarszemu monasterowi supraskiemu biskup Józef pozyskał względy zwierzchnika Cerkwi w Konstantynopolu. Wszystko to wzmacniało kandydaturę władyki smoleńskiego w jego staraniach o objęcie godności metropolity kijowskiego. Według Efima Cereteliego Józef Sołtan został obrany na metropolitę wskutek zabiegów wielkiej księżnej Heleny i księcia Konstantego Ostrogskiego ${ }^{99}$. Chirotonia władyki Józefa Sołtana na metropolitę nastąpiła 10 maja 1507 roku $^{100}$. Według innych źródeł władyka Józef był ,nareczennym" metropolitą jeszcze 26 lutego 1508 roku $^{101}$.

Interesujący w tym wypadku jest dokument z 26 lutego 1507 roku wystawiony w Wilnie na wniosek Józefa Sołtana i Aleksandra Chodkiewicza przez króla Zygmunta Starego. Monarcha potwierdzał w nim przekazanie klasztorowi sześciu służb kmiecych, które biskup smoleński otrzymał w 1503 roku $^{102}$. Dokument ten

${ }^{94}$ Hieronim Grala datuje otrzymanie nadania trzech wsi w powiecie bielskim Józefowi Sołtanowi na wrzesień 1503 r., H. Grala, Kotpak Witołdowy czy czapka Monomacha? (Dylematy wyznawców prawostawia w monarchii ostatnich Jagiellonów) [w:] Katolicyzm w Rosji i prawosławie w Polsce (XI-XX w.), J. Bardach et al. (red.), Warszawa 1997, s. 61, przyp. 3.

${ }_{95}$ A. Łapiński, op. cit., s. 37.

${ }^{96}$ H. Lulewicz, op. cit., s. 359.

${ }^{97}$ „Vestnik Zapadnoi Rossii”, g. IV, kn. 7, t. III, otd. 2, Vil'no 1865/1866, s. 1-6.

${ }^{98}$ Kopia dokumentu, por:: Archiwum Państwowe w Krakowie, Archiwum Młynowskie Chodkiewiczów, sygn. 36, nr 29, k. 81-83; ASD, t. IX, Vil'no 1870, s. 6-7; „Vestnik Zapadnoi Rossii”, g. V, kn. 7, t. I, otd. 2, Vil'no 1867, s. 6-9; list króla Aleksandra nadający biskupowi smoleńskiemu Józefowi Sołtanowi dobra Baciuty, Topilec i Piszczewo z 15 września 1504 r., ASD, t. IX, Vil'no 1870, s. 8-9 (wydrukowany z błędną datą roczną).

${ }^{99}$ E. Tserenteli, op. cit., s. 301.

100 „Vestnik Zapadnoi Rossii”, g. IV, kn. 7, t. III, otd. 2, Vil'no 1865/1866, s. 2. Książę Konstanty Ostrogski poczynił wybranemu metropolicie liczne zapisy. Akty, otnosiashchiiesia k istorii Zapadnoi Rossii, sobrannye i izdannye Arkheograficheskoju komissieju, t. II, 1506-1544, Sankt-Peterburg 1848, s. 26-27; Af. Yarushevich, op. cit., s. 95.

101 „Lietuvos Metrika”, Knyga nr 8 (1499-1514): Užrašymu knyga 8, parengè A. Baliulis, R. Firkovičius, D. Antanavičius, Vilnius 1995, nr 110, s. 143. Błogosławieństwo na godność metropolity kijowskiego od patriarchy konstantynopolitańskiego Pachomiusza władyka Józef otrzymał dopiero w 1509 r. Metropolita Józef tytułował się jako metropolita kijowski, halicki i całej Rusi. Sprawując funkcję metropolity, Józef Sołtan najczęściej rezydował w Wilnie i Mińsku.

102 Archiwum Państwowe w Krakowie, Archiwum Młynowskie Chodkiewiczów, sygn. 36, nr 29, k. 83-84; $A S D$, t. IX, Vil'no 1870, s. 22-24. Regest tego dokumentu wskazuje, że wydanie nastąpiło 17 lipca 1507 r., Prawa i przywileje miasta i dóbr ziemskich Zabłudów XV-XVIII w., J. Maroszek (oprac.), 
potwierdzający przekazanie klasztorowi przez władykę smoleńskiego otrzymanych od króla dóbr Topilec, Baciuty i Piszczewo zawiera w swej treści wiele istotnych informacji. W dokumencie tym znajduje się następujący zapis: „a moia brat'ia i moi prirozhonnyi ne majut" sia v" to vstupati, ani poiskivati, bo iesmi dal" to na tserkov' Bozhiju svoju vlastnuju vyslugu, majuchi ieie vechno, nizhli kto byli na potom" rodu moiego zhivi, tot" povinen" toie imen'ie ot" krivd" boroniti, dlia togo, aby tserkvi Bozhie ispolna sluzhilo"103. Przy tego typu zapisie, jeżeli metropolita miałby dzieci, z pewnością zostałyby one wymienione w tym dokumencie. Zapis potwierdza, że metropolita Józef nie posiadał potomków, a jedynie braci.

Dodatkowo, z powodu uszczuplenia majątku biskupiego, namiestnik smoleński Jerzy (Jurii) Adrzejewicz Sołłohuba przekazał 18 lipca 1507 roku władyce smoleńskiemu Józefowi puste sioło Kapustinskoje na Smoleńszczyźnie. Nadanie to osobnym przywilejem potwierdził 18 lipca 1507 roku Zygmunt Stary i dołączył je do uposażenia cerkwi sobornej Narodzenia NMP w Smoleńsku ${ }^{104}$. Zaufanie władz państwowych do biskupa smoleńskiego Józefa Sołtana było duże. Wszystkie ważniejsze akty i nadania królewskie dotyczące spraw cerkiewnych, wojskowych, gospodarczych i administracyjnych na terenie Smoleńszczyzny były adresowane do władyki Józefa, chociaż jego bezpośrednio nie dotyczyły ${ }^{105}$.

Władyka Sołtan był również wymieniony na pierwszym miejscu wśród odbiorców przywileju wydanego przez wielkiego księcia Aleksandra mieszkańcom Smoleńska 1 marca 1505 roku, potwierdzającego nadania poprzednich władców litewskich. Wynagradzając wierność wobec dynastii, książę Aleksander Jagiellończyk gwarantował przywrócenie dawnych praw - „stariny”, uwzględnionej w przywilejach Kazimierza Jagiellończyka i jego poprzedników. Panujący potwierdził zmniejszenie obciążeń mieszczan i bojarów na Smoleńszczyźnie na rzecz skarbu hospodarskiego oraz namiestników smoleńskich. Przywilej zawierał również gwarancje praw Cerkwi prawosławnej na Smoleńszczyźnie, nienaruszalnej dominacji prawosławia, nieobciążanie duchowieństwa i wiernych prawosławnych dodatkowymi podatkami, zachowanie praw i przywilejów monasterów i cerkwi oraz poszanowanie własności cerkiewnej (uposażeń) ${ }^{106}$. Przywilej hospodarski był nagrodą za postawę rodziny Sołtanów i mieszkańców Smoleńska podczas ostatniej wojny z Moskwą. Smoleńsk sprostał wówczas trzem oblężeniom wojsk moskiewskich. Przywilej księcia Aleksandra umacniał wierność wobec domu Jagiellońskiego przed przewidywanym

Białystok 1994, s. 86. Potwierdzenie Zygmunta Starego nadania monasterowi supraskiemu ziemi przez władykę smoleńskiego Józefa Sołtana w 1504 r. - Biblioteka Muzeum Narodowego im. Czartoryskich w Krakowie, Zbiór dokumentów pergaminowych, nr 53. (MNK 540/13).

${ }^{103}$ Nikolai (Dalmatov), Suprasl'skii Blagoveshchenskii monastyr', Sankt-Peterburg 1892, s. 12.

104 „Lietuvos Metrika”, Knyga nr 8 (1499-1514), op. cit., nr 228, s. 206-207; H. Lulewicz, op. cit., s. 360

105 „Lietuvos Metrika”, Knyga nr 8 (1499-1514), op. cit., nry: 94, 110, 220, 230, 238, 243, 252.

${ }_{106}$ Przywilej władyce, bojarom $i$ wszystkim mieszczanom smoleńskim na ich prawa $i$ wolności, „Lietuvos Metrika”, Knyga nr 5 (1427-1506): Užrašymu knyga 5, parengė E. Banionis, Vilnius 1993, nr 157, s. $272-275$. 
kolejnym etapem konfliktu z Księstwem Moskiewskim. Podpisany rozejm w 1503 roku miał bowiem trwać do 25 marca 1509 roku $^{107}$.

Metropolita Józef (Eliasz) miał więc dwóch braci: starszego Michała - wymienionego w przywileju Zygmunta Starego ${ }^{108}$ - i młodszego Hrynka. Z przywileju królewskiego wynika, że książę Semen Aleksandrowicz Czartoryski dał w 1496 roku Michałowi Sołtanowi dwie służby we wsi Haniewiczach, gdzie „siedzieli Piotr z braćmi”, będący na służbie namiestników łohojskich. Michał Sołtan zmarł bezdzietnie, a schedę po nim otrzymali w 1516 roku bracia zmarkego: metropolita Józef i młodszy Hryńko, a nie jego potomstwo, którego się nie doczekał ${ }^{109}$. Z pewnością córkę miał Hryńko, młodszy brat metropolity. W Archiwum Świętego Synodu znajdował się wpis, z którego wynikało, że metropolita miał dwie siostry: Mariannę, która wyszła za mąż za Wasyla Hornostaja ${ }^{110}$, i Annę, która została małżonką księcia Aleksandra Czartoryskiego ${ }^{111}$. To drugie małżeństwo nastąpiło po powrocie księcia na Litwę i po śmierci poprzedniej małżonki księcia - Marii, córki Dymitra Szemiaki w lutym 1456 roku. Ślub księcia Aleksandra Czartoryskiego z Anną Sołtan odbył się między 1462 a 1477 rokiem. Być może Semen Aleksandrowicz był synem księcia Aleksandra Czartoryskiego i Anny Sołtan. Ten drugi alians małżeński tłumaczyłby, dlaczego książęta Czartoryscy odnosili się do rodziny Sołtanów z taką życzliwością.

Dobra należące do bojarów Sołtanów znajdowały się w powiecie łohojskim oraz na innych terenach Wielkiego Księstwa Litewskiego, ale zawsze obok ziem należących do Czartoryskich. Podobnie było z dobrami należącymi do metropolity Józefa. Zestawienie dóbr posiadanych przez bojara Eliasza i jego braci potwierdza takie samo zabezpieczenie materialne (rodowe) metropolity Józefa. Wieś Haniewicze Józef Sołtan otrzymał po śmierci swego brata Michała, na co król wydał specjalny dokument w 1516 roku$^{112}$.

Józef Sołtan prowadził spory majątkowe, między innymi w 1516 roku z księżną Zofią Holszańską i marszałkiem hospodarskim Stanisławem Bartoszewiczem oraz kapitułą wileńską o dwie służby dane w Haniewiczach przypadających mu po

107 O wojnie smoleńskiej z lat 1500-1502 zob. J. Natanson Leski, Dzieje granicy wschodniej Rzeczypospolitej. Część I., Granica moskiewska w epoce jagiellońskiej, Lwów-Warszawa 1922, s. 87-91; M.M. Krom, Mezh Rus'iu i Litvoi. Pogranichnye zemli v sisteme russko-litovskikh otnoshenii kontsa XV-pervoi treti XVI v., Moskva 2010, s. 184-185; W. Białowiejska, Stosunki Litwy z Moskwa w pierwszej połowie panowania Aleksandra Jagiellończyka, „Atheneum Wileńskie” 1930, R. VII, z. 3-4, s. 726-785; H. Łowmiański, Polityka Jagiellonów, Poznań 1999, s. 236; A. Krupska, Z dziejów tworzenia się nowego uktadu sit politycznych w Europie Wschodniej po upadku Złotej Ordy w XV w., „Roczniki Historyczne” 1976, R. XLII, s. 37-56.

108 Akty, otnosiashchiiesia k istorii Jugo-Zapadnoi Rossii, t. I, op. cit., nr 62.

109 Według A. Bonieckiego Michał Sołtanowicz miał córkę, która w 1517 r. nie była pełnoletnia, A. Boniecki, Poczet rodów w Wielkim Księstwie Litewskim w XV i XVI wieku, Warszawa 1887, s. 331. Informacja ta nie jest prawdziwa, albowiem gdyby u Michała Sołtana - zmarłego w $1496 \mathrm{r}$ - była córka, to miałaby by ona w 1517 r. 21 lat, a więc byłaby osobą dorosłą.

${ }^{110}$ Wasyl Hornostaj był synem Hornostaja Romanowicza, klucznika kijowskiego (1486), namiestnika owruckiego (1487), który zginął w wojnie z Tatarami w 1503 r. Zob.: J. Wolff, op. cit., s. 659; A. Boniecki, op. cit., s. 86.

111 Nikolai (Dalmatov), op. cit., s. 487.

${ }_{112}$ Akty, otnosiashchiiesia $k$ istorii Zapadnoi Rossii, sobrannye i izdannye Arkheograficheskoju komissieju, t. II, op. cit., s. 146, 154; AJuZR, cz. 1, t. I, Kiev 1859, s. 3-5. 
starszym bracie Michale. W obydwu przypadkach Zygmunt Stary potwierdził prawo Sołtanów do spornych ziem. 19 stycznia 1516 roku król polecił swoim komisarzom i sędziom udać się do rodowych dóbr metropolity Józefa, aby na miejscu rozstrzygnąc spór z Holszańskimi i Bartoszewiczami, którzy „kriwdy velikiia diejut’ v zemliakh ego otchiznykh" "113. Podobnie ci sami komisarze królewscy 1 lutego 1516 roku mieli zdecydować w sprawie służb ze wsi Haniewicze na ziemi, do której rościła pretensje kapituła Świętego Stanisława w Wilnie. Król potwierdził prawo metropolity na piątą część dani miodowej, która pochodziła z Haniewicz, ale inne dochody z tej wsi zachowała kapituła wileńska. Spór ten toczył się aż do śmierci metropolity bez rozstrzygnięcia sądowego. Dopiero w 1532 roku Juchno Wańkowicz ponownie wytoczył proces przeciwko kanonikom wileńskim o ziemie we wsi Haniewicze. Król Zygmunt I potwierdził 9 maja 1538 roku prawo Juchny Wańkowicza do wsi Haniewicze pod Łohojskiem z trzema służbami osób nazwanych Osipowiczowymi. Dobra te uprzednio należały do Hryńka i Eliasza Sołtanów. Powodem jego starań był fakt, że córka Hryńka Sołtana, Anna, była żoną księcia Wasyla Iwanowicza Puzyny, pochodzącego ze Smoleńszczyzny właściciela dóbr Nosowo w powiecie mielnickim ${ }^{114}$, a następnie Juchny Wańkowicza ${ }^{115}$.

Z zaprezentowanych ustaleń wynika, że pogląd o pochodzeniu rodu metropolity Józefa Sołtana $\mathrm{z}$ linii łohojskiej jest w pełni wiarygodny w konfrontacji z imionami osób wymienionymi w supraskim Subbotniku ili Pominniku. Z analizy tego dokumentu wynika, że znajdują się w nim imiona osób z rodziny arcybiskupa Józefa Sołtana, a Eliasz Sołtan, będący na służbie hospodarskiej z ziemi łohojskiej, to ta sama osoba co metropolita Józef.

${ }^{113}$ Cytat za A. Beletskii, op. cit., s. 28.

114 Wieś Nosowo, w 1513 r. należała do dzierżawy mielnickiej. Na przełomie XV i XVI w. Nosowo stało się własnością Heleny, żony Aleksandra Jagiellończyka. W 1516 r. księżna nadała wieś Iwanowi Puzynie, po którym dobra przejął jego syn Wasyl Iwanowicz. Po jego śmierci pozostawała w dożywocie przy wdowie Annie Sołtan, następnie od 1528 r. Nosowo przeszło na własność dworzanina królewskiego, Juchny Wańkiewicza, który został jej drugim mężem. Na terenie wsi znajdowała się cerkiew parafialna św. Michała Archanioła wybudowana przed 1542 r. przez Juchnę Wańkiewicza. W 1541 r. Zygmunt Stary przekazał Nosowo Iwanowi Wasylewiczowi Lackiemu (Ladzkiemu). Po nim wieś odziedziczył jego syn Iwan Iwanowicz, leśniczy podlaski. W 1609 r. sprzedana przez Teodora Iwanowicza Lackiego Warszyckiemu. W 1642 r. wieś została sprzedana Janowi Firlejowi, wojewodzie sandomierskiemu, a rok później wojewodzie brzeskiemu Krzysztofowi Piekarskiemu. W 1669 r. Nosowo zostało przekazane zięciowi właściciela, Sawickiemu, którego syn w 1688 r. sprzedał majątek Janowi Pieniążkowi, kasztelanowi brzeskiemu. Od 1700 r. do 1780 r. Nosowo było własnością Sedlnickich, następnie do 1945 r. - Wężyków.

115 J. Wolff, op. cit., s. 406; A. Beletskii, op. cit., s. 28-30, 39-42. 


\section{Bibliografia}

\section{Źródla rękopiśmienne}

Archiwum Państwowe w Krakowie, Archiwum Młynowskie Chodkiewiczów, sygn. 36, nr 29.

Biblioteka Muzeum Narodowego im. Czartoryskich w Krakowie, Zbiór dokumentów pergaminowych, nr 53 (MNK 540/13).

\section{Źródla drukowane}

Akty, otnosiashchiiesia k istorii Jugo-Zapadnoi Rossii, t. I, Sankt-Peterburg 1863.

Akty, otnosiashchiiesia k istorii Zapadnoi Rossii, sobrannye i izdannye Arkheograficheskoju komissieju, t. II, 1506-1544, Sankt-Peterburg 1848.

Arkheograficheskii sbornik dokumentov, otnosiashchikhsia k Istorii Severo-Zapadnoi Rusi, izdavaiemyi pri upravlenii Vilenskogo uchebnogo okruga, t. IX, Vil'no 1870; t. XI, Vil'no 1890.

Arkhiv Jugo-Zapadnoi Rossii, izdavaiemyi Vremennoju komissiieju dlia razbora drevnikh aktov, vysochaishe uchrezhdennoju pri Kiievskom voiennom, Podol'skom i Volynskom general-gubernatore, cz. 1, t. I, Kiev 1859; cz. 1, t. VI: Akty o tserkovno-religioznykh otnosheniiakh v JugoZapadnoi Rusi (1322-1648 g.), Kiev 1883.

Daniłowicz J., Skarbiec dyplomów papieskich, książęcych, uchwat narodowych, postanowień różnych władz i urzędów postugujących do krytycznego wyjaśnienia dziejów Litwy, Rusi Litewskiej i ościennych innych krajów, t. II, Wilno 1862.

E.N., Staryi sinodik Suprasl’skogo monastyria, „Grodnenskiie Eparkhial'nyie Vedomosti” 1904, № 27.

Fijałek J., Kopiarz rzymski, „Archiwum Komisji Historycznej”, seria II, t. I, Kraków 1923.

Kulesza J.A., Wiara prawosławna pismem świętym, soborami, Oycami SS. mianowicie greckiemi y historya kościelna przez X. Jana Aloyzego Kuleszę Societatis Jesu Theologa objaśniona, od przyiętey Unii Boga z człowiekiem roku 1747 w Wilnie w drukarni Akademickiey SJ., Wilno 1747.

„Lietuvos Metrika”, Knyga nr 5 (1427-1506): Užrašymų knyga 5, parengė E. Banionis, Vilnius 1993.

„Lietuvos Metrika”, Knyga nr 8 (1499-1514): Užrašymu knyga 8, parengė A. Baliulis, R. Firkovičius, D. Antanavičius, Vilnius 1995.

Mironowicz A., Subotnik ili Pominnik monasteru supraskiego, Białystok 2015.

Pomenyk Sofiyi Kyyivs'koyi: publikatsiya rukopysnoyi pam'yatky druhoyi Polovynykhviii-pershoyi chverti XIX st., uporyadok ta vstupni statti O. Prokop'yuk, Kyiv 2004 (Nekropolistyka v Ukrayini, vyp. 3(8)).

Prawa i przywileje miasta i dóbr ziemskich Zabłudów XV-XVIII w., J. Maroszek (oprac.), Białystok 1994.

Sołtan A.L., Kronika żałobna, T. Żychliński (red.), Poznań 1877.

Stebelski I., Dwa Wielkie Światła na Horyzoncie Połockim z Cieniów Zakonnych Powstajace, czyli Żywoty SS. Panien y Matek Ewfrozyny y Parascewii, Zakonnic y Hegumeniy, Pod Ustawa S. O. Bazylego W. w Monastyrze S. Spasa za Połockiem żyjacych, z Chronologia y Przydatkiem Niektórych Stużąych do tego Pożytecznych Krajowych Wiadomości, z Rozmaitych Dziejopisow y Pism zebranych, przez X. W. Ignacego Stebelskiego Zakonu S. Bazylego W. Prowincyi Litew: Okazane, y za Pozwoleniem Zwierzchności do Druku Podane Roku Pańskiego 1781, tomik I. W Wilnie w Drukarni Bazylianskiey, Wilno 1781.

Stebelski I., O Prześwietnej Familii JMść PP. Soltanów [w:] Ostatnie Stebelskiego prace z autografu wydał, wstępem i przypisami objaśnit dr Władysław Seredyński, „Sciptores Rerum Polonicarum", t. IV, Kraków 1874.

„Vestnik Zapadnoi Rossii”, g. IV, kn. 7, t. III, otd. 2, Vil'no 1865/1866. 
„Vestnik Zapadnoi Rossii”, g. V, kn. 7, t. I, otd. 2, Vil'no 1867.

„Vestnik Zapadnoi Rossii”, g. V, kn. 7, t. III, otd. 2, Vil’no 1866/1867.

\section{Literatura}

Afanasii (Martos), Belarus v istoricheskoi, gosudarstvennoi i tserkovnoi zhizni, Buenos-Aires 1966.

Beletskii A., Rodoproiskhozhdeniie zapadnoruskago mitropolita Iosifa II Soltana, Vil'no 1895.

Białowiejska W., Stosunki Litwy z Moskwa w pierwszej połowie panowania Aleksandra Jagiellończyka, „Atheneum Wileńskie” 1930, R. VII, z. 3-4, s. 726-785.

Boniecki A., Poczet rodów w Wielkim Księstwie Litewskim w XV i XVI wieku, Warszawa 1887.

Chodynicki K., Kościót prawosławny a Rzeczypospolita Polska, Warszawa 1934.

Grala H., Kotpak Witołdowy czy czapka Monomacha? (Dylematy wyznawców prawostawia $w$ monarchii ostatnich Jagiellonów) [w:] Katolicyzm $w$ Rosji $i$ prawostawie $w$ Polsce (XI-XX w.), J. Bardach et al. (red.), Warszawa 1997.

Herbarz rodzin tatarskich w Polsce, S. Dziadulewicz (oprac.), Wilno 1929.

Jarushevich Af., Revnitel' pravoslaviia, kniaz' Konstantin Ivanovich Ostrozhskii (1461-1530) i pravoslavnaia Litovskaia Rus'v iego vremia, Smolensk 1896.

„Kievskiie Eparkhial'nyie Vedomosti” 1873, otd. II.

Korczak L., Litewska Rada wielkoksiążęca w XV wieku, Kraków 1998.

Krom M.M., Mezh Rus'iu i Litvoi. Pogranichnye zemli v sisteme russko-litovskikh otnoshenii kontsa XV-pervoi treti XVI v., Moskva 2010.

Krupska A., Z dziejów tworzenia się nowego układu sit politycznych w Europie Wschodniej po upadku Złotej Ordy w XV w., „Roczniki Historyczne” 1976, R. XLII, s. 37-56.

Kuczyński S.M., Czartoryski Semen Aleksandrowicz [w:] Polski Słownik Biograficzny, t. IV, W. Konopczyński et al. (red.), Kraków 1938, s. 296-297.

Ljubavskii M.K., Oblastnoie deleniie i mestnoie samoupravleniie Litovsko-russkogo gosudarstva, Moskva 1892.

Lulewicz H., Soltan Józef [w:] Polski Słownik Biograficzny, t. LX, z. 3, W. Konopczyński et al. (red.), Warszawa-Kraków 2001, s. 359-361.

Łapiński A., Zygmunt Stary a Kościót prawosławny, Warszawa 1937.

Łowmiański H., Polityka Jagiellonów, Poznań 1999.

Maroszek J., Pogranicze Litwy i Korony w planach króla Zygmunta Augusta, Białystok 2000.

Mironowicz A., Jozafat Dubieniecki. Historia cudownego obrazu żyrowickiego, „Zeszyty Naukowe KUL” 1994, R. XXXIV, nr 1-2 (133-134), s. 213-232.

Mironowicz A., Kościół prawosławny w dziejach dawnej Rzeczypospolitej, Białystok 2001.

Mironowicz A., Największa fundacja Aleksandra Chodkiewicza. Spór o charakter fundacji [w:] Władza i prestiż. Magnateria Rzeczypospolitej w XVI-XVIII wieku, J. Urwanowicz (red.), Białystok 2003, s. 529-550.

Mironowicz A., O poczatkach monasteru supraskiego i jego fundatorach, Supraśl 2013.

Mironowicz A., Powstanie monasteru supraskiego, „Białostockie Teki Historyczne” 2012, nr 10, s. 29-40.

Mitropolit Makarii, Istoriia Russkoi Tserkvi, kn. V, Moskva 1996.

Mitropolit Makarii, Istoriia Russkoi Tserkvi, t. IX, Sankt-Peterburg 1879.

Modest (Strel'bitskii), Suprasl'skii Blagoveshchenskii monastyr', „Vestnik Zapadnoi Rossii. Istoriko-literaturnyi zhurnal" 1867, g. V, kn. 6, t. II, otd. 2, s. 128-131.

Natanson Leski J., Dzieje granicy wschodniej Rzeczypospolitej. Część I., Granica moskiewska w epoce jagiellońskiej, Lwów-Warszawa 1922.

Nikolai (Dalmatov), Suprasl'skii Blagoveshchenskii monastyr', Sankt-Peterburg 1892.

Shchaviskaia L.L., Literaturnaia kul'tura belorusov Podliash'ia XV-XIX vv., Knizhnyie sobraniia Suprasl'skogo Blagoveshchenskogo monastyria, Minsk 1998.

Słownik Geograficzny Królestwa Polskiego i innych krajów słowiańskich, F. Sulimierski, B. Chlebowski, W. Walewski (red.), t. IV, Warszawa 1883; t. XII, Warszawa 1882. 
Sołtan A.L., Aleksander Sołtan. Szambelan Karola Zuchwatego i Kawaler Złotego Runa „Przegląd Poznański” 1862, t. XXXIII, s. 65-80.

Tserenteli E., Elena Ioannovna, velikaia kniaginia litovskaia, russkaia, koroleva pol'skaia, Sankt-Peterburg 1899.

Wolff J., Kniaziowie litewsko-ruscy od końca czternastego wieku, Warszawa 1895. 